Article

\title{
Fluorescent Dendritic Micro-Hydrogels: Synthesis, Analysis and Use in Single-Cell Detection
}

\author{
Lisa Christadore $^{1}$, Mark W. Grinstaff ${ }^{1,2, * \text { (I) }}$ and Scott E. Schaus ${ }^{1, *}$ \\ 1 Department of Chemistry, Boston University, Boston, MA 02215, USA; lmchristadore1@gmail.com \\ 2 Departments of Biomedical Engineering and Medicine, Boston University, Boston, MA 02215, USA \\ * Correspondence: mgrin@bu.edu (M.W.G.); seschaus@bu.edu (S.E.S.); Tel.: +1-617-358-3429 (M.W.G.); \\ +1-617-353-2489 (S.E.S.)
}

Academic Editor: Ashok Kakkar

Received: 21 March 2018; Accepted: 11 April 2018; Published: 18 April 2018

\begin{abstract}
Hydrogels are of keen interest for a wide range of medical and biotechnological applications including as 3D substrate structures for the detection of proteins, nucleic acids, and cells. Hydrogel parameters such as polymer wt $\%$ and crosslink density are typically altered for a specific application; now, fluorescence can be incorporated into such criteria by specific macromonomer selection. Intrinsic fluorescence was observed at $\lambda_{\max } 445 \mathrm{~nm}$ from hydrogels polymerized from lysine and aldehyde- terminated poly(ethylene glycol) macromonomers upon excitation with visible light. The hydrogel's photochemical properties are consistent with formation of a nitrone functionality. Printed hydrogels of $150 \mu \mathrm{m}$ were used to detect individual cell adherence via a decreased in fluorescence. The use of such intrinsically fluorescent hydrogels as a platform for cell sorting and detection expands the current repertoire of tools available.
\end{abstract}

Keywords: dendrimer; hydrogel; screening; crosslinking; fluorescence

\section{Introduction}

Dendrimers are well-defined macromolecules with unique properties that are advantageous for a wide range of applications [1-4], with particular utility in medical and biotechnological systems [5-10]. For example, dendrimer-based delivery vehicles for anticancer drugs provide new approaches to tune cellular uptake and pharmacokinetics [11-20]. Multifunctionalized dendritic macromonomers are of interest for the formation of crosslinked hydrogels to repair bone [21] and soft tissues [22-28], to engineer cartilage tissue scaffolds [29,30], to deliver drugs [31,32], and to prepare microarrays for screening protein and nucleic acid interactions [33]. The latter study led us to the discovery of intrinsic fluorescence emitted by hydrogels prepared from PEG-(CHO $)_{2}$ and PEG-(Lys) $)_{2}$, PEG-(Lys $\left.)_{2}\right)_{2}$, or [G1]-Lys- $\mathrm{NH}_{2}$ macromonomers. The macromonomers rapidly polymerized on aldehyde-coated slides to yield Schiff-base crosslinked hydrogels. When the hydrogel microarrays were analyzed with a fluorescent scanner, distinct fluorescence was observed that persisted over multiple days and washes with aqueous buffer. Herein, we describe the visible fluorescence, propose the origin of its emission, and develop a hydrogel label-free single-cell assay.

Previous studies described fluorescence from amine-containing poly(amido amine) and poly(propylene imine) dendrimers in solution with emission maximums between 440 and $450 \mathrm{~nm}$ upon excitation at $\approx 380 \mathrm{~nm}$ [34-38]. Several groups reported that dendrimer fluorescence intensified with prolonged exposure to oxygen. Furthermore, emission intensities increased linearly with dendrimer concentrations and were unaffected by terminal group composition. These results suggested that the fluorescence was directly related to the dendrimers' common tertiary amine and/or amide backbones. Recent studies by Qian et al. suggest that the imine bond in the imidic acid group present within the 
PAMAM structure is responsible for emission $[39,40]$. In our studies, we propose that aerobic oxidation of the imine may be responsible for the fluorescence observed from the Schiff-base crosslinked hydrogels.

\section{Results and Discussion}

We employed steady-state spectrofluorimetry and confocal fluorescence microscopy to analyze hydrogel fluorescence (Figure 1, top). Figure 1 middle depicts the excitation and emission fluorescence profiles of the Schiff-base crosslinked hydrogel. The excitation maximum was observed at $380 \mathrm{~nm}$, and emission occurred over a broad range with a maximum at $445 \mathrm{~nm}$. These results indicated a unique fluorescent structure existed within the hydrogel network that exhibited a relatively large Stokes shift $(65 \mathrm{~nm})$ and a wide emission bandwidth $(\mathrm{FWHM}=89 \mathrm{~nm})$. Fluorescence is not observed with amide-crosslinked hydrogels prepared from the reaction between Lys-terminated and PEG-(NHS) 2 macromonomers.

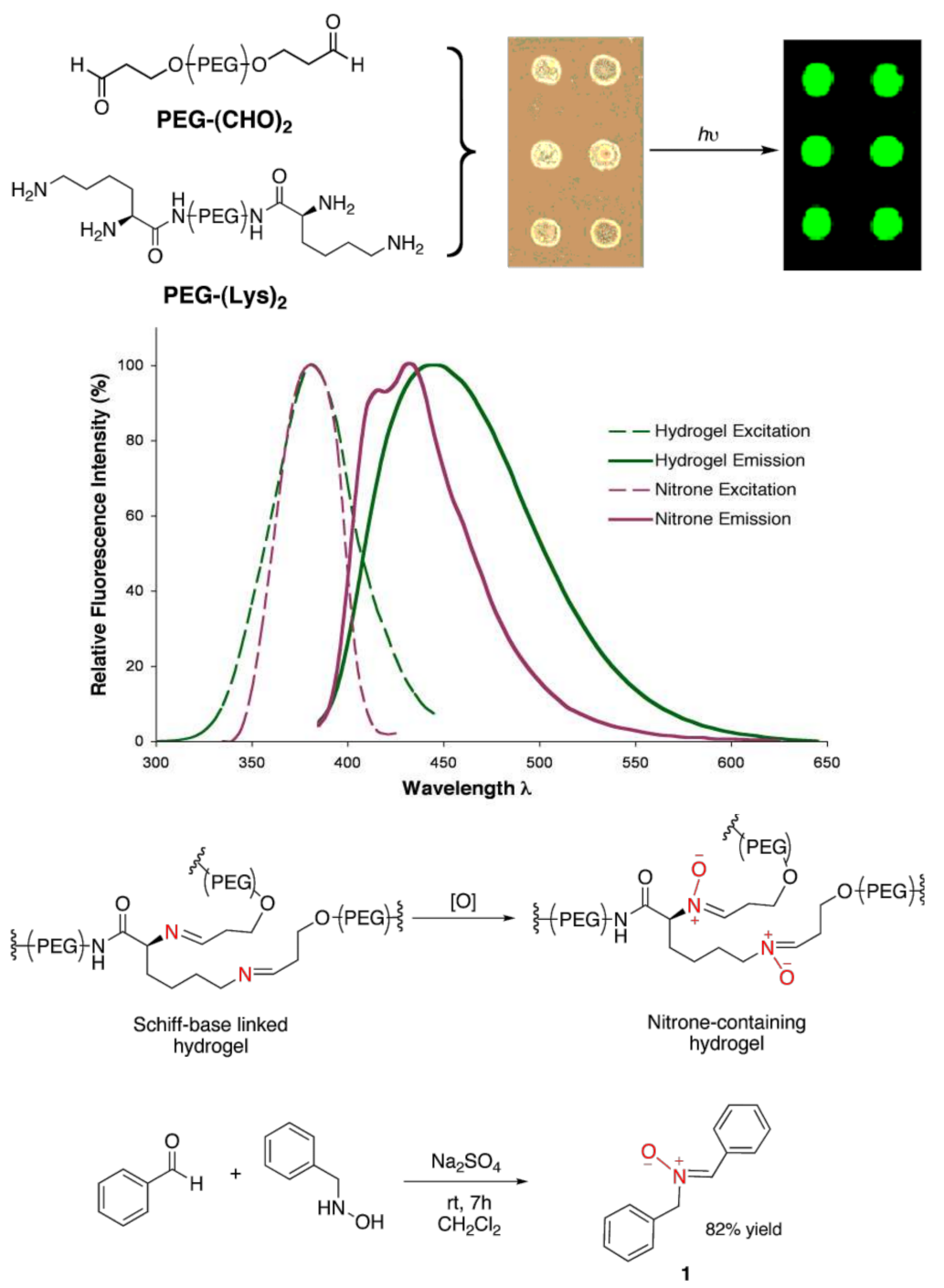

Figure 1. (top) PEG-(CHO) 2 and PEG-(Lys) $)_{2}$ were mixed in situ and dispensed onto aldehyde-coated slides to form $150 \mu \mathrm{m}$ hydrogel chambers using an OmniGrid accent microarrayer. Fluorescence emission was observed between $550-590 \mathrm{~nm}$ on a GenePix 4000B microarray scanner. (middle) Fluorescence spectra of the Schiff-base linked hydrogel, 14 wt \% 2:1 PEG-(CHO) 2 :PEG-(Lys) ${ }_{2}$, polymerized in HEPES buffer $\mathrm{pH} 7.4$ for $24 \mathrm{~h}$ (green), and (Z)- $N$-benzyl- $\alpha$-phenylnitrone, 1, in ethanol at $2.8 \mathrm{wt} \%$ immediately following solvation (purple) (bottom). Proposed air oxidation scheme of the hydrogel imine linkages to nitrones (top), and synthesis scheme of $\mathbf{1}$ (bottom). 
We next addressed the possible chemical structure and mechanism responsible for the unique fluorescence properties of the hydrogel. Specifically, the imine functionality and the photochemical properties of its oxidation products were investigated. Previous studies have demonstrated nitrone formation by aerobic oxidation of secondary amines and imines. Such syntheses have utilized oxygen and hydrogen peroxide as primary oxidants, typically in conjunction with transition metal [41-45] and flavin-derived $[46,47]$ catalysts. Thus, we proposed that air oxidation of the imine to the nitrone may be responsible for the observed hydrogel fluorescence (Figure 1, top).

Accordingly, a model nitrone compound, (Z)- $N$-benzyl- $\alpha$-phenylnitrone 1, was synthesized [48] to compare fluorescent properties (Figure 1, bottom). The excitation spectrum of $\mathbf{1}$ in ethanol showed a maximum at $380 \mathrm{~nm}$, similar to the Schiff-base crosslinked hydrogel. Emission maxima were observed at 415 and $435 \mathrm{~nm}$ (Figure 1, middle). The dual emission peaks of the nitrone were attributed to photochemical isomerization of the $Z$ isomer to the oxaziradine intermediate via an excited singlet state.

The double emission peaks observed for $\mathbf{1}$ upon steady-state excitation are likely due to the nitrone's rearrangement to an oxaziradine intermediate via the lowest singlet excited state. Various isomerization mechanisms and activation energy barriers have been published for aryl-substituted nitrones under photolysis conditions [49-56]. For example, photochemical-induced rearrangement of $N$, $\alpha$-diphenyl- $\alpha$-cyanonitrone to its corresponding oxaziradine occurred from the lowest singlet excited state when irradiated with $313 \mathrm{~nm}$ light. Oxaziradine formation was indicated by the decrease in nitrone absorbance at $322 \mathrm{~nm}$ and the emergence of a new band at $223 \mathrm{~nm}$. Infrared spectra at $77^{\circ} \mathrm{K}$ showed the disappearance of characteristic $\mathrm{C}=\mathrm{N}$ and $\mathrm{N} \rightarrow \mathrm{O}$ nitrone stretching and the presence of oxaziradine ring vibrations [55]. Another group reported the photorearrangement of chiral aryl-substituted nitrones to optically active oxaziradines when excited at wavelengths greater than $300 \mathrm{~nm}$ [49]. Furthermore, photolysis studies of $N, \alpha$-diphenylnitrone indicated a $20 \mathrm{~nm}$ hypsochromic absorbance band shift that was attributed to the singlet transition of the nitrone to its oxaziradine intermediate [52].

In the last decade, cell sorting and microfluidic technologies have enabled advancements on many fronts including the study of individual cells and the diagnosis of disease states [57-67]. Given both the favorable characteristics of hydrogels as artificial extracellular matrix scaffolds and the intrinsic fluorescence observed with these specific hydrogels, we evaluated this system to detect single cells via the abatement or loss of hydrogel fluorescence signal upon individual cell binding.

Specifically, printed hydrogel microarrays were treated with a bovine serum albumin (BSA) solution and excited by a $405 \mathrm{~nm}$ laser diode using a confocal microscope. The emission was monitored from 450 to $500 \mathrm{~nm}$ as transmitted through a beam splitter, and 3D photon surface plots of the hydrogel chambers were obtained (as shown in Figure 2a). Next, human A549 small cell lung carcinoma cells were incubated with the hydrogel microarrays and washed to remove unbound cells. As can be seen in the photon surface plots, the adhered cells significantly obstructed fluorescence throughout the entire hydrogel network with a hydrogel:cell signal-to-noise ratio of 3.4:1 (Figure $2 b-d$ ). 

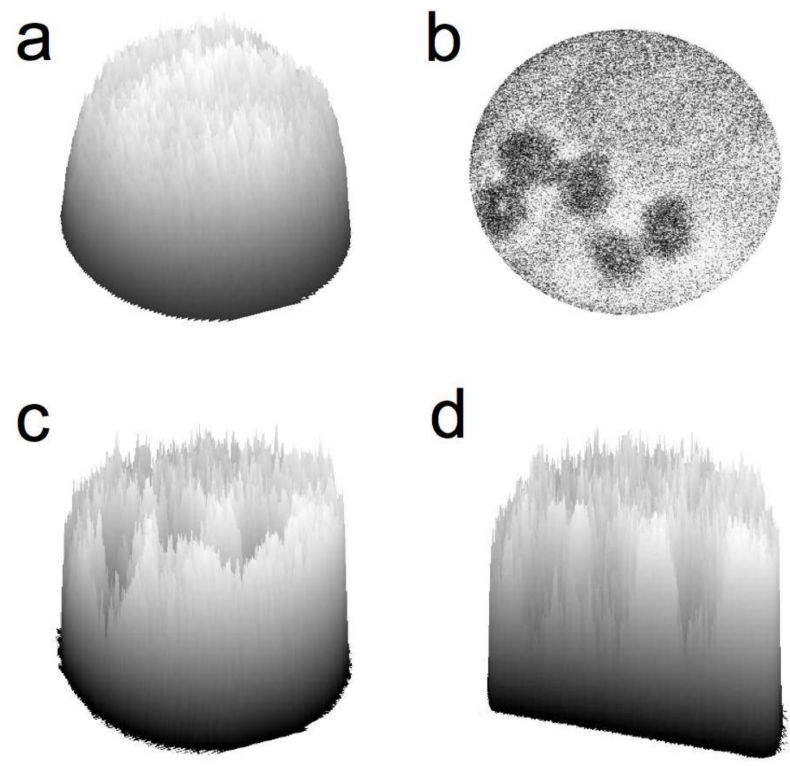

Figure 2. Scanning confocal microscopy images of BSA-treated hydrogels, 22 wt \% 2:1 PEG-(CHO) 2 :PEG-(Lys) $)_{2}$. Emission was collected at $460 \mathrm{~nm}$, subtracted from slide background, and normalized to 8-bits/pixel. (a) 3D surface plot of a hydrogel chamber in the absence of cell adhesion, (b) 2D depiction of cells masking hydrogel emission fluorescence, (c) 3D surface plot of the hydrogel shown in $\mathbf{b}$, and (d) $3 \mathrm{D}$ cross-section of the hydrogel shown in $\mathbf{b}$.

\section{Materials and Methods}

\subsection{General Information}

${ }^{1} \mathrm{H}-\mathrm{NMR}$ was recorded on a Varian INOVA at $400 \mathrm{MHz}$ at ambient temperature. Chemical shifts are reported in parts per million as follows: chemical shift, multiplicity $(\mathrm{s}=$ singlet, $\mathrm{d}=$ doublet, $\mathrm{t}=$ triplet, $\mathrm{q}=$ quartet, $\mathrm{m}=$ multiplet, $\mathrm{br}=$ broad) and integration. Infrared spectra were recorded on a Nicolet Nexus 670 FT-IR ESP spectrophotometer. Analytical thin layer chromatography was performed using EMD $0.25 \mathrm{~mm}$ silica gel 60-F plates. Reverse phase chromatography was performed on a C8-bonded silica extraction column (United Chemical Technologies, Horsham, PA, USA). Sub-micro fluorimeter quartz cells were supplied by Starna Cells, Inc. (Atascadero, CA, USA). All solvents were purchased from Pharmco-AAPER or Fisher Scientific as highest purity grade or dispensed dry from a solvent purification system $\left(\mathrm{CH}_{2} \mathrm{Cl}_{2}\right)$. Other synthetic reagents were obtained from commercial sources and used without further purification unless indicated. Benzaldehyde was distilled prior to use. NanoPure ${ }^{\mathrm{TM}}$ water (Barnstead International, Dubuque, IA, USA) was used for all microarray and cell processing procedures. 384-well plates were purchased from Genetix (Boston, MA, USA) and SuperAldehyde slides were purchased from TeleChem International (Sunnyvale, CA, USA). Cell culture and seeding materials were supplied by Fisher Scientific (Hampton, NH, USA) and Invitrogen (Carlsbad, CA, USA). Hydrogel microarrays were produced using an OmniGrid Accent ${ }^{\mathrm{TM}}$ Microarrayer (GeneMachines, San Carlos, CA, USA). Scanner fluorescence images were obtained on a GenePix 4000B microarray scanner and data analysis was done using GenePix 3.0 software (Axon Instruments, Union City, CA, USA). Fluorescence spectra were taken on a QuantaMaster ${ }^{\mathrm{TM}}$ Luminescence spectrofluorimeter and data was analyzed using FeliX32 ${ }^{\mathrm{TM}}$ software (Photon Technology International, Birmingham, NJ, USA) and Microsoft Office ${ }^{\circledR}$ Excel. Confocal fluorescence imaging of hydrogels was performed with an Olympus Fluoview ${ }^{\mathrm{TM}} 1000$ scanning laser confocal microscope, controlled by Olympus FV10-ASW v1.61 software (Center Valley, PA, USA). Fluorescence emission data were acquired as the integrated photon intensity within a defined hydrogel region. Images were processed and analyzed with ImageJ [68]. 


\subsection{Hydrogel Array Materials E Methods}

Preparation of 2-iodoxybenzoic acid (IBX): Oxone (133.80 g, $0.218 \mathrm{~mol}$ ) was added to a 1-L round bottom flask and suspended in $520 \mathrm{~mL}$ of distilled water. 2-iodobenzoic acid ( $30 \mathrm{~g}, 0.121 \mathrm{~mol})$ was added in one portion and the reaction mixture heated to $70^{\circ} \mathrm{C}$ and stirred for $3 \mathrm{~h}$. The reaction was cooled to room temperature and then to $0^{\circ} \mathrm{C}$ for $90 \mathrm{~min}$ to further precipitate the product. The resulting white solid was collected by filtration, washed with water $(5 \times 50 \mathrm{~mL})$ and acetone $(4 \times 50 \mathrm{~mL})$, and dried under vacuum to afford the pure product $(27 \mathrm{~g}, 80 \%$ yield). The spectral data were in agreement with reported values [69].

Preparation of poly(ethylene glycol) dialdehdye (PEG-(CHO) 2 ) macromonomer (Figure 3): Poly(ethylene glycol) $\mathrm{Mn}=3400 \mathrm{~g} / \mathrm{mol}(3 \mathrm{~g}, 0.882 \mathrm{mmol})$ was dissolved in toluene $(10 \mathrm{~mL})$, concentrated under reduced pressure to a viscous residue, and dried under vacuum $(2 \times)$. The residue was dissolved in a minimum of ethyl acetate (approx. $20 \mathrm{~mL})$ and IBX $(1.24 \mathrm{~g}, 4.4 \mathrm{mmol})$ was added in one portion. The reaction mixture was heated to $80^{\circ} \mathrm{C}$ and stirred for $20 \mathrm{~h}$. IBX was filtered over Celite and the filtrate was concentrated under reduced pressure to a thin residue. An additional filtration in ethyl acetate removed any remaining IBX. The product was concentrated under pressure and precipitated in cool ether for $2 \mathrm{~h}$ to afford crude PEG-(CHO $)_{2}(0.8 \mathrm{~g}, 27 \%$ yield $)$. The crude product was purified by reversed phase chromatography using a C8-bonded silica endcapped column (elution with $10-90 \%$ acetonitrile in water), and the product was lyophilized to afford pure PEG-(CHO) $)_{2}$. ${ }^{1} \mathrm{H}-\mathrm{NMR}$ (400 MHz, $\mathrm{CDCl}_{3}$ ): 3.62-3.72 (m, 340, $\mathrm{CH}_{2}$ of PEG); 4.14 (m, 2, $\mathrm{CH}_{2} \mathrm{CHO}$ ); 9.71 (s, 1, CHO).

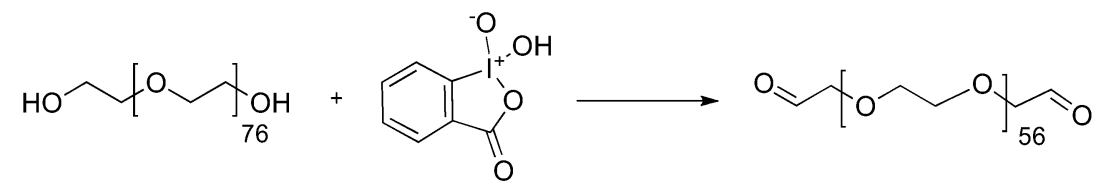

Figure 3. Synthesis scheme of the poly(ethylene glycol) dialdehdye (PEG-(CHO) 2 ) macromonomer.

Preparation of bis(2-amido-lysine)-poly(ethylene glycol) (PEG-(Lys) 2 ) macromonomer: According to literature procedure [70].

Printing of hydrogel microarrays: The hydrogel solution (22 wt \% 2:1 PEG-(CHO) $2:$ PEG-(Lys) 2 in HEPES buffer $\mathrm{pH}$ 7.4) was printed on aldehyde-coated glass slides, polymerized for $24 \mathrm{~h}$ at room temperature and blocked with a $1 \% w / v$ BSA solution in water as previously reported [33]. Fluorescence measurements were performed as described below. Attempts to observe the nitrone in the gel by IR were unsuccessful.

A549 cell seeding conditions: Cells were cultured at $37^{\circ} \mathrm{C}$ in a $5 \% \mathrm{CO}_{2}$ atmosphere in Dulbecco's modified Eagle medium (DMEM) supplemented with $10 \%$ fetal bovine serum and $10 \mu \mathrm{g} / \mathrm{mL}$ penicillin. Immediately prior to incubation with hydrogel microarrays, cells were detached from polystyrene culture flasks, centrifuged at $1000 \times g$ for $5 \mathrm{~min}$, and re-suspended in the appropriate volume of phosphate buffered saline (PBS) to yield $\sim 3 \times 10^{4}$ cells $/ \mathrm{mL}$. The cell solution was slowly pipetted directly on top of the hydrogels in a $100 \times 20 \mathrm{~mm}$ polystyrene culture dish and incubated for $20 \mathrm{~min}$ at $37^{\circ} \mathrm{C}$. Microarrays were then washed with PBS $(10 \mathrm{~mL})$ to remove unbound cells and tapped dry.

\subsection{Fluorescence Image Analysis}

GenePix 4000B microarray fluorescence scans: Following microarray printing, the macromonomers were allowed to polymerize for $24 \mathrm{~h}$ at room temperature. The crosslinked hydrogel chambers were excited with the microarray scanner and emission intensities were calculated as the mean intensity of the spot normalized to the background.

Steady-state fluorescence spectra: The hydrogel solution (14 wt \% 2:1 PEG-(CHO) 2 :PEG(Lys) $\left.)_{2}\right)$ was contained in a $10 \mathrm{~mm}$ pathlength quartz cuvette under atmospheric conditions $24 \mathrm{~h}$ prior to fluorescence measurements. The samples were excited by a pulsed xenon lamp at a wavelength of 
$380 \mathrm{~nm}$, and emission was monitored from 300-600 nm as the number of photon counts per second. Excitation and emission were controlled by a quarter-meter class, Czerny-Turner type monochromator with a standard 1200 line/mm ruled grating. Spectra data was corrected for solvent background, and counts per second were normalized to an arbitrary scale of 0-100.

Confocal fluorescence imaging: The hydrogel microarrays were printed and blocked with BSA solution as described above. For cell seeding hydrogel experiments, the microarray slides were further incubated with a solution of A549 human lung carcinoma cells for 20 min at $37^{\circ} \mathrm{C}$, washed with PBS, and tapped dry. Both blank and cell-seeded hydrogel arrays were imaged on a confocal scanning electron microscope with a $20 \times$ water-immersion objective lens. A $407 \mathrm{~nm}$ diode laser was used for excitation of the intrinsic hydrogel fluorescence, and detection was carried out between 450 and $500 \mathrm{~nm}$ at $20 \mu \mathrm{s} /$ pixel resolution. Confocal emission spectra were generated using sequential emission imaging of the hydrogel at $5 \mathrm{~nm}$ bandpass between 440 and $600 \mathrm{~nm}$. Maximum hydrogel emission, with minimal background interference, occurred at $460 \mathrm{~nm}$.

Data were analyzed as the integrated pixel intensity (at $460 \mathrm{~nm}$ emission) within the area of a manually outlined hydrogel chamber, human cell, or background region. Fluorescence 2D images and 3D surface plots corresponding to the emission intensity of an outlined hydrogel chamber subtracted from slide background were constructed in Image (Figure 2 in paper). Images were formatted to 8-bits per pixel (grayscale LUT) and contrast was enhanced. Signal-to-noise ratios were determined as the mean pixel intensity within a hydrogel area or cell area divided by the corresponding standard deviation.

\subsection{Nitrone Model}

Preparation of $\mathrm{N}$-benzylhydroxylamine [71]. A flame dried flask was charged with a stir bar and benzaldehyde oxime $(1.00 \mathrm{~g}, 8.26 \mathrm{mmol})$ dissolved in methanol $(9.03 \mathrm{~mL}, 0.223 \mathrm{~mol})$ was added. Sodium cyanoborohydride $(0.363 \mathrm{~g}, 5.78 \mathrm{mmol})$ was added and the $\mathrm{pH}$ was brought down to $\mathrm{pH} 4$ with the addition of aqueous concentrated $\mathrm{HCl}$. The reaction was stirred for $3 \mathrm{~h}$. Solvent was concentrated under reduced pressure and crude product was diluted with $6 \mathrm{M}$ potassium hydroxide and washed with brine. The organic layer was extracted with chloroform $(3 \times)$ and dried over $\mathrm{MgSO}_{4}$. The product was concentrated and ${ }^{1} \mathrm{H}-\mathrm{NMR}$ spectroscopy showed sufficient purity to be used in the next reaction.

Preparation of (Z)-N-benzyl- $\alpha$-phenylnitrone (1; Figure 4): According to the procedure of Chang, et al. [48], a flame dried $5 \mathrm{~mL}$ round bottom flask was charged with a stir bar and flushed with nitrogen. To this flask was added anhydrous sodium sulfate $(0.160 \mathrm{~g}, 1.125 \mathrm{mmol})$, $\mathrm{N}$-benzylhydroxylamine $(0.092 \mathrm{~g}, 0.75 \mathrm{mmol})$, benzaldehyde $(0.111 \mathrm{~g}, 1.05 \mathrm{mmol})$, and dichloromethane $(2.5 \mathrm{~mL})$. The reaction was stirred under nitrogen at room temperature for $7 \mathrm{~h}$. Sodium sulfate was filtered and the filtrate was concentrated under reduced pressure to give a light brown oil that solidified upon standing. The crude product was washed once with cold petroleum ether and recrystallized from hexane $(2 \times)$ to afford $0.13 \mathrm{~g}(82 \%$ yield) of the $Z$ isomer. The spectral data was in agreement with reported values [72].

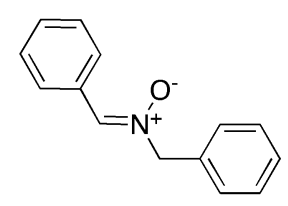

Figure 4. Chemical structure of nitrone, 1.

Photochemical properties: Steady-state fluorescence spectra were taken of $\mathbf{1}(2.8 \mathrm{wt} \%, 0.13 \mathrm{M})$ immediately following dissolution in either ethanol or dichloromethane. Fluorescence intensity was weaker and dual peak emission less pronounced in $\mathrm{EtOH}$ as compared to $\mathrm{CH}_{2} \mathrm{Cl}_{2}$ as result of the increased solvation of $\mathbf{1}$ due to $\mathrm{H}$-bonding interactions. However, excitation and emission maxima 
were consistent between both solvents, and EtOH solvent fluorescence data was used for hydrogel fluorescence comparisons. The nitrone solution was contained in a $10 \mathrm{~mm}$ pathlength quartz cuvette and fluorescence measurements were taken under the same conditions as described for the hydrogel. Spectra data was corrected for background, and counts per second were normalized to an arbitrary scale of $0-100$.

\section{Conclusions}

In summary, fluorescence emission is observed from the hydrogels with a $\lambda_{\max }$ at $445 \mathrm{~nm}$. The photochemical properties of these hydrogels are consistent with emission from a nitrone functionality formed via oxidation of the imine crosslinkages within the hydrogel. A new cell microarray assay is described, whereby the reduction or obstruction of fluorescence is monitored upon individual cell adherence to the hydrogel chamber. Typically, hydrogel parameters such as polymer wt $\%$ and crosslink density are altered for a specific application; now, fluorescence can be incorporated into such criteria by specific macromonomer selection. Continued experimentation with multifunctional dendritic macromolecules will lead to new polymer structures, crosslinked networks, and properties broadening the investigation of these unique macromolecules for basic and clinical applications.

Acknowledgments: This research was supported by Boston University. We thank Michel Wathier and Phil Allen for help with the experiments.

Author Contributions: L.C., M.W.G. and S.E.S. conceived and designed the experiments; L.C. performed the experiments; L.C., M.W.G. and S.E.S. analyzed the data; L.C., M.W.G. and S.E.S. wrote the paper.

Conflicts of Interest: The authors declare no conflict of interest.

\section{References}

1. Caminade, A.M.; Ouali, A.; Laurent, R.; Turrin, C.O.; Majoral, J.P. Coordination chemistry with phosphorus dendrimers. Applications as catalysts, for materials, and in biology. Coord. Chem. Rev. 2016, 308, $478-497$. [CrossRef]

2. Sun, H.J.; Zhang, S.; Percec, V. From structure to function via complex supramolecular dendrimer systems. Chem. Soc. Rev. 2015, 44, 3900-3923. [CrossRef] [PubMed]

3. Wang, D.; Astruc, D. Dendritic catalysis-Basic concepts and recent trends. Coord. Chem. Rev. 2013, 257, 2317-2334. [CrossRef]

4. Newkome, G.R.; Shreiner, C.D. Poly(amidoamine), polypropylenimine, and related dendrimers and dendrons possessing different $1 / 2$ branching motifs: An overview of the divergent procedures. Polymer 2008, 49, 1-173. [CrossRef]

5. Molla, M.R.; Rangadurai, P.; Pavan, G.M.; Thayumanavan, S. Experimental and theoretical investigations in stimuli responsive dendrimer-based assemblies. Nanoscale 2015, 7, 3817-3837. [CrossRef] [PubMed]

6. Kannan, R.M.; Nance, E.; Kannan, S.; Tomalia, D.A. Emerging concepts in dendrimer-based nanomedicine: From design principles to clinical applications. J. Intern. Med. 2014, 6, 579-617. [CrossRef] [PubMed]

7. Mintzer, M.A.; Grinstaff, M.W. Biomedical Applications of Dendrimers: A Tutorial. Chem. Soc. Rev. 2011, 40, 173-190. [CrossRef] [PubMed]

8. Lee, C.C.; MacKay, J.A.; Fréchet, J.M.J.; Szoka, F.C. Designing Dendrimers for Biological Applications. Nat. Biotechnol. 2005, 23, 1517-1526. [CrossRef] [PubMed]

9. Svenson, S.; Tomalia, D.A. Dendrimers in Biomedical Application-Reflections on the Field. Adv. Drug Deliv. Rev. 2005, 57, 2106-2129. [CrossRef] [PubMed]

10. Grinstaff, M.W. Biodendrimers: New Polymeric Materials for Tissue Engineering. Chem. Eur. J. 2002, 8, 2838-2846. [CrossRef]

11. Shaunak, S. Perspective: Dendrimer drugs for infection and inflammation. Biochem. Biophys. Res. Commun. 2015, 468, 435-441. [CrossRef] [PubMed]

12. Wu, L.P.; Ficker, M.; Christensen, J.B.; Trohopoulos, P.N.; Moghimi, S.M. Dendrimers in Medicine: Therapeutic Concepts and Pharmaceutical Challenges. Bioconj. Chem. 2015, 26, 1198-1211. [CrossRef] [PubMed] 
13. Bugno, J.; Hsu, H.; Hong, S. Recent advances in targeted drug delivery approaches using dendritic polymers. Biomater. Sci. 2015, 3, 1025-1034. [CrossRef] [PubMed]

14. Wolinsky, J.B.; Grinstaff, M.W. Therapeutic and Diagnostic Applications of Dendrimers for Cancer Treatment. Adv. Drug Deliv. Rev. 2008, 60, 1037-1055. [CrossRef] [PubMed]

15. Gillies, E.R.; Frechet, J.M. Dendrimers and dendritic polymers in drug delivery. Drug Discov. Today 2005, 10, 35-43. [CrossRef]

16. Lee, C.C.; Gillies, E.R.; Fox, M.E.; Guillaudeu, S.J.; Fréchet, J.M.J.; Dy, E.E.; Szoka, F.C. A single dose of doxorubicin-functionalized bow-tie dendrimer cures mice bearing C-26 colon carcinoma. Proc. Natl. Acad. Sci. USA 2006, 103, 16649-16654. [CrossRef] [PubMed]

17. Lim, J.; Simanek, E.E. Synthesis of water-soluble dendrimers based on melamine bearing 16 paclitaxel groups. Org. Lett. 2008, 10, 201-204. [CrossRef] [PubMed]

18. Gurdag, S.; Khandare, J.S.S.; Matherly, L.H.; Kannan, R.M. Activity of dendrimer methotrexate conjugates on methotrexate-sensitive and resistant cell lines. Bioconj. Chem. 2006, 17, 275-283. [CrossRef] [PubMed]

19. Morgan, M.T.; Nakanishi, Y.; Kroll, D.J.; Griset, A.P.; Carnahan, M.A.; Wathier, M.; Oberlies, N.H.; Manikumar, G.; Wani, M.C.; Grinstaff, M.W. Dendrimer-encapsulated camptothecins: Increased solubility, cellular uptake, and cellular retention afford enhanced anticancer activity in vitro. Cancer Res. 2006, 66, 11913-11921. [CrossRef] [PubMed]

20. Morgan, M.T.; Carnahan, M.A.; Immoos, C.E.; Ribeiro, A.A.; Finkelstein, S.; Lee, S.J.; Grinstaff, M.W. Dendritic molecular capsules for hydrophobic compounds. J. Am. Chem. Soc. 2003, 125, 15485-15489. [CrossRef] [PubMed]

21. Hed, Y.; Oberg, K.; Berg, S.; Nordberg, A.; von Holst, H.; Malkoch, M. Multipurpose heterofunctional dendritic scaffolds as crosslinkers towards functional soft hydrogels and implant adhesives in bone fracture applications. J. Mater. Chem. B 2013, 1, 6015-6019. [CrossRef]

22. Ghobril, C.; Grinstaff, M.W. The Chemistry and Engineering of Polymeric Hydrogel Adhesives for Wound Closure: A Tutorial. Chem. Soc. Rev. 2015, 44, 1820-1835. [CrossRef] [PubMed]

23. Ghobril, C.; Charoen, K.; Rodriguez, E.K.; Nazarian, A.; Grinstaff, M.W. A Dendritic Thioester Hydrogel Based on Thiol-Thioester Exchange as a Dissolvable System for Wound Closure. Angew. Chem. Int. Ed. 2013, 52, 14070-14074. [CrossRef] [PubMed]

24. Oelker, A.M.; Grinstaff, M.W. Ophthalmic Adhesives: A Materials Chemistry Perspective. J. Mater. Chem. 2008, 18, 2521-2536. [CrossRef]

25. Wathier, M.; Jung, P.J.; Carnahan, M.A.; Kim, T.; Grinstaff, M.W. Dendritic Macromers as In Situ Polymerizing Biomaterials for Securing Cataract Incisions. J. Am. Chem. Soc. 2004, 126, 12744-12745. [CrossRef] [PubMed]

26. Carnahan, M.A.; Middleton, C.; Kim, J.; Kim, T.; Grinstaff, M.W. Hybrid Dendritic-Linear Polyester-ethers for In Situ Photopolymerization. J. Am. Chem. Soc. 2002, 124, 5291-5293. [CrossRef] [PubMed]

27. Wathier, M.; Johnson, S.M.; Kim, T.; Grinstaff, M.W. Hydrogels Formed by Multiple Peptide Ligation Reactions to Fasten Corneal Transplants. Bioconj. Chem. 2006, 17, 873-876. [CrossRef] [PubMed]

28. Berdahl, J.P.; Johnson, C.S.; Proia, A.D.; Grinstaff, M.W.; Kim, T. Comparison of Sutures and New Dendritic Polymer Adhesives for Corneal Laceration Repair in an In Vivo Chicken Model. Arch. Ophthalmol. 2009, 127, 442-447. [CrossRef] [PubMed]

29. Degoricija, L.; Söntjens, S.H.M.; Bansal, P.N.; Takahashi, M.; Joshi, N.; Snyder, B.; Grinstaff, M.W. Hydrogels for Osteochondral Regeneration Based on Photo-crosslinkable Carbamate Dendrimers. Biomacromolecules 2008, 9, 2863-2872. [CrossRef] [PubMed]

30. Sontjens, S.H.M.; Nettles, D.L.; Carnahan, M.A.; Setton, L.A.; Grinstaff, M.W. Biodendrimer-based hydrogel scaffolds for cartilage tissue repair. Biomacromolecules 2006, 7, 310-316. [CrossRef] [PubMed]

31. Navath, R.S.; Menjoge, A.R.; Dai, H.; Romero, R.; Kannan, S.; Kannan, R.M. Injectable PAMAM dendrimer-PEG hydrogels for the treatment of genital infections: Formulation, in-vitro and in-vivo evaluation. Mol. Pharm. 2011, 8, 1209-1223. [CrossRef] [PubMed]

32. Yang, H.; Tyagi, P.; Kadam, R.S.; Holden, C.A.; Kompella, U.B. Hybrid dendrimer hydrogel/PLGA nanoparticle platform sustains drug delivery for one week and antiglaucoma effects for four days following one-time topical administration. ACS Nano 2012, 6, 7595-7606. [CrossRef] [PubMed]

33. Dominguez, M.M.; Wathier, M.; Grinstaff, M.W.; Schaus, S.E. Immobilized Hydrogels for High Throughput Screening of Molecular Interactions. Anal. Chem. 2007, 79, 1064-1066. [CrossRef] [PubMed] 
34. Larson, C.L.; Tucker, S.A. Intrinsic fluorescence of carboxylate-terminated polyamido amine dendrimers. Appl. Spectrosc. 2001, 55, 679-683. [CrossRef]

35. Lee, W.I.; Bae, Y.B.; Bard, A.J. Strong blue photoluminescence and ECL from OH-terminated PAMAM dendrimers in the absence of gold nanoparticles. J. Am. Chem. Soc. 2004, 126, 8358-8359. [CrossRef] [PubMed]

36. Wang, D.; Imae, T. Fluorescence emission from dendrimers and its $\mathrm{pH}$ dependence. J. Am. Chem. Soc. 2004, 126, 13204-13205. [CrossRef] [PubMed]

37. Wang, D.; Imae, T.; Miki, M. Fluorescence emission from PAMAM and PPI dendrimers. J. Colloid Interface Sci. 2007, 306, 222-227. [CrossRef] [PubMed]

38. Tsai, Y.J.; Hu, C.C.; Chu, C.C.; Imae, T. Intrinsically fluorescent PAMAM dendrimer as gene carrier and nanoprobe for nucleic acids delivery: Bioimaging and transfection study. Biomacromolecules 2011, 12, 4283-4290. [CrossRef] [PubMed]

39. Ji, Y.; Qian, Y. A study using quantum chemical theory methods on the intrinsic fluorescence emission and the possible emission mechanisms of PAMAM. RSC Adv. 2014, 4, 58788-58794. [CrossRef]

40. Ji, Y.; Yang, X.-L.; Qian, Y. Poly-amidoamine structure characterization: Amide resonance structure of imidic acid (HO-C[double bond, length as m-dash]N) and tertiary ammonium. RSC Adv. 2014, 4, 49535-49540. [CrossRef]

41. Ballistreri, F.P.; Barbuzzi, E.; Tomaselli, G.A.; Toscano, R.M.; Mol, J.C. Oxidation of N, N-benzylalkylamines to nitrones by Mo(VI) and W(VI) polyperoxo complexes. Catal. A Chem. 1997, 114, 229. [CrossRef]

42. Cardona, F.; Bonanni, M.; Soldaini, G.; Goti, A. One-Pot Synthesis of Nitrones from Primary Amines and Aldehydes Catalyzed by Methyltrioxorhenium. ChemSusChem 2008, 1, 327-332. [CrossRef] [PubMed]

43. Feuer, H. Nitrile Oxides, Nitrones and Nitronates; John Wiley \& Sons, Inc.: Hoboken, NJ, USA, 2008.

44. Soldaini, G.; Cardona, F.; Goti, A. Catalytic Oxidation of Imines Based on Methyltrioxorhenium/Urea Hydrogen Peroxide: A Mild and Easy Chemo- and Regioselective Entry to Nitrones. Org. Lett. 2007, 9, 473-476. [CrossRef] [PubMed]

45. Thiel, W.R. Transition metal mediated oxygen transfer to organo nitrogen compounds. Coord. Chem. Rev. 2003, 245, 95-106. [CrossRef]

46. Imada, Y.; Iida, H.; Ono, S.; Murahashi, S. Flavin catalyzed oxidations of sulfides and amines with molecular oxygen. J. Am. Chem. Soc. 2003, 125, 2868-2869. [CrossRef] [PubMed]

47. Murahashi, S. Synthetic Aspects of Metal-Catalyzed Oxidations of Amines and Related Reactions. Angew. Chem. Int. Ed. 1995, 34, 2443-2465. [CrossRef]

48. Chang, Z.Y.; Coates, R.M. Diastereoselectivity of organometallic additions to nitrones bearing stereogenic N-substituents. J. Org. Chem. 1990, 55, 3464-3474. [CrossRef]

49. Boyd, D.R.; Campbell, P.B.; Grimshaw, J.; Neill, D.C.; Jennings, W.B. Dynamic stereochemistry of imines and derivatives. Part 18. Photosynthesis and photoracemization of optically active oxaziridines. J. Chem. Soc. Perkin Trans. 1985, 1, 849-855. [CrossRef]

50. Cik, G.; Sersen, F. A study of photolysis of N-(4-azidobenzylidene)aniline-N-oxide. J. Imaging Sci. 1991, 35, 14-19.

51. Cyr, D.R.; Mathew, T.; Ashok, K.; Das, P.K.; George, M.V. A laser flash photolysis study of aromatic nitrones. Triplet state properties and reactivity with singlet oxygen. J. Photochem. Photobiol. A Chem. 1991, 60, 161-174. [CrossRef]

52. Khoee, S.; Memarian, H.R. Fluorescence self-quenching of substituted $N, \alpha$-diphenylnitrones in various solvents. J. Photochem. Photobiol. A Chem. 2006, 177, 276-285. [CrossRef]

53. Koyano, K.; Tanaka, I. The Photochemical and Thermal Isomerization of trans- and cis- $\alpha$-Cyano- $\alpha$-phenyl-N-phenylnitrones. J. Phys. Chem. 1965, 69, 2545-2550. [CrossRef]

54. Lamchen, M.; Mittag, T.W. Nitrones. Part VII. The photochemistry and cycloaddition of a monocyclic

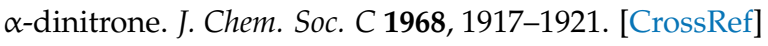

55. Shinzawa, K.; Tanaka, I. The Photochemical Isomerization of $\alpha, N$-Diphenylnitrone. J. Phys. Chem. 1964, 68, 1205-1213. [CrossRef]

56. Splitter, J.S.; Calvin, M. Oxaziridines. I. The Irradiation Products of Several Nitrones1. J. Org. Chem. 1965, 30, 3427-3436. [CrossRef]

57. Brehm-Stecher, B.F.; Johnson, E.A. Single-cell microbiology: Tools, technologies, and applications. Microbiol. Mol. Biol. Rev. 2004, 68, 538-559. [CrossRef] [PubMed] 
58. Dittrich, P.S.; Manz, A. Lab-on-a-chip: Microfluidics in drug discovery. Nat. Rev. Drug Discov. 2006, 5, 210. [CrossRef] [PubMed]

59. El-Ali, J.; Sorger, P.K.; Jensen, K.F. Cells on chips. Nature 2006, 442, 403-411. [CrossRef] [PubMed]

60. Vilkner, T.; Janasek, D.; Manz, A. Micro Total Analysis Systems. Recent Developments. Anal. Chem. 2004, 76, 3373-3386. [CrossRef] [PubMed]

61. Wheeler, A.R.; Throndset, W.R.; Whelan, R.J.; Leach, A.M.; Zare, R.N.; Liao, Y.H.; Farrell, K.; Manger, I.D.; Daridon, A. Microfluidic device for single-cell analysis. Anal. Chem. 2003, 75, 3581-3586. [CrossRef] [PubMed]

62. Zare, R.N.; Kim, S. Microfluidic platforms for single-cell analysis. Annu. Rev. Biomed. Eng. 2010, 12, $187-201$. [CrossRef] [PubMed]

63. Tan, S.J.; Li, Q.; Lim, C.T. Manipulation and isolation of single cells and nuclei. Methods Cell Biol. 2010, 98, 79-96. [PubMed]

64. Yershov, G.; Barsky, V.; Belgovskiy, A.; Kirillov, E.; Kreindlin, E.; Ivanov, I.; Parinov, S.; Guschin, D.; Drobyshev, A.; Dubiley, S.; et al. DNA analysis and diagnostics on oligonucleotide microchips. Proc. Natl. Acad. Sci. USA 1996, 93, 4913-4918. [CrossRef] [PubMed]

65. Zlatanova, J.; Mirzabekov, A. Gel-Immobilized Microarrays of Nucleic Acids and Proteins. Production and Application for Macromolecular Research. Methods Mol. Biol. 2001, 170, 17-38. [PubMed]

66. Beria, L.; Gevrek, T.N.; Erdog, A.; Sanyal, R.; Pasini, D.; Sanyal, A. Clickable Hydrogels for All: Facile Fabrication and Functionalization. Biomater. Sci. 2014, 2, 67-75. [CrossRef]

67. Kemp, M.M.; Weïwer, M.; Koehler, A.N. Unbiased binding assays for discovering small-molecule probes and drugs. Bioorg. Med. Chem. 2012, 20, 1979-1989. [CrossRef] [PubMed]

68. Rasband, W.S. ImageJ. U. S.; National Institutes of Health: Bethesda, MD, USA, 2008. Available online: https:/ /imagej.nih.gov/ij/ (accessed on 17 April 2018).

69. Frigerio, M.; Santagostino, M.; Sputore, S. A User-Friendly Entry to 2-Iodoxybenzoic Acid (IBX). J. Org. Chem. 1999, 64, 4537-4538. [CrossRef]

70. Wathier, M.; Johnson, M.S.; Carnahan, M.A.; Baer, C.; McCuen, B.W.; Kim, T.; Grinstaff, M.W. In situ polymerized hydrogels for repairing scleral incisions used in pars plana vitrectomy procedures. ChemMedChem 2006, 1, 821-825. [CrossRef] [PubMed]

71. Kainthan, R.K.; Mugabe, C.; Burt, H.M.; Brooks, D.E. Unimolecular micelles based on hydrophobically derivatized hyperbranched polyglycerols: Ligand binding properties. Biomacromolecules 2008, 9, 886-895. [CrossRef] [PubMed]

72. Murahashi, S.; Mitsui, H.; Shiota, T.; Tsuda, T.; Watanabe, S. Tungstate-catalyzed oxidation of secondary amines to nitrones. .alpha.-Substitution of secondary amines via nitrones. J. Org. Chem. 1990, 55, 1736-1744. [CrossRef]

Sample Availability: Samples of the compounds are available from the authors.

(C) 2018 by the authors. Licensee MDPI, Basel, Switzerland. This article is an open access article distributed under the terms and conditions of the Creative Commons Attribution (CC BY) license (http:/ / creativecommons.org/licenses/by/4.0/). 